\title{
Work and Retirement : Future Prospects for the Baby-Boom Generation
}

\author{
by Geneviève Reday-Mulvey*
}

\section{Introduction}

On 29 and 30 November 1989 a symposium on the Future of Retirement was held in Chicago, USA. It was organized by the American Society of Actuaries, the EBRI (The Employee Benefit Research Institute) and Chicago's National Pension Research Council.

The American Society of Actuaries had asked a number of Institutes from a fairly wide range of fields to prepare a scenario of retirement - or more exactly of the lives of men and women over sixty years - twenty-five years from now, that is, in the year 2013. The International Association for the Study of Insurance Economics - for short the Geneva Association - was one of the 6 Institutes invited to prepare a scenario for the Symposium.

The scenarios presented in Chicago obviously varied in a number of respects, but practically all had one idea in common, namely that retirement, as we have known it over the last 25 years or so, will in future years undergo certain very significant changes. Briefly put, by the year 2013, people would be living longer, working differently and would see their professional life extended and its pattern altered.

When, in 1986, the Geneva Association launched the idea of the 4th Pillar it was this altered and extended pattern of professional life that was considered. What, then, is the 4th Pillar?

In most Western countries, pension or retirement schemes are based on three pillars: - A basic Pension provided by the State (called Social Security in some countries): 1st Pillar - A supplementary Professional or Occupational Pension: 2d Pillar

- Personal Savings: 3d Pillar.

The 4th Pillar, then, refers to the idea of an increasing portion of the population over 60 years (without any upper limit at, for example 65 or 70 years of age) being able to remain professionally active in remunerated flexible and part-time employment.

The current aging of the population in our countries will gather momentum over the next couple of decades making acute the problem of financing the retirement of an economically dependent $3 \mathrm{~d}$ age population. What steps, then, over the next decade or so, should be taken to alleviate this situation: reduce the pensions of the baby-boom generation? Raise further the already high contributions drawn on the incomes of a work-force whose

\footnotetext{
* Economist and Psychosociologist, Research fellow, International Association for the Study of Insurance Economics, Geneva.
} 
number is already shrinking? Should we go back the way we have come and, like the Americans, raise the legal age of retirement for everybody? Or should we increase the volume of savings beyond current levels?

These solutions - a relative cut in pensions, an increase in contributions, a raising of the retirement age, and accumulation of savings - are being studied by various bodies, in particular by the ILO (International Labour Organisation), the ISSA (International Association for Social Security) and the Commission of the European Communities, and it is clear that, combined in different ways, they could help to alleviate the situation of some countries.

It is however already obvious that the advantages of the 4th Pillar - combining partial retirement with part-time employment - will prove to be very real as much from a psychosociological standpoint as from an economic one. But before considering these advantages, it might be well to examine the growth trends for pensions and for the population.

\section{Growth trends - pension expenditure and population}

During the post-war period, pensions rose much more sharply than the GDP in all western countries. For example, between 1960 and 1983, in OECD member countries as a whole the average rise in public expenditure on retirement has more than doubled from $4.9 \%$ to $10.3 \%$; in some countries this expenditure has more than tripled. Here are some examples :

$T A B L E 1$

Public Retirement Expenditure (as a \% of National Income)

$\begin{array}{lrr} & 1960 & 1984 \\ \text { France } & 6.7 & 14.3 \\ \text { Germany } & 10.6 & 13.7 \\ \text { Italy } & 5.9 & 16.9 \\ \text { Sweden } & 4.9 & 12.9 \\ \text { Austria } & 10.9 & 16.5 \\ \text { Japan } & 1.6 & 6.0\end{array}$

Source: OECD, Reforming Public Pensions, Paris 1988.

This phenomenal growth is of course in part due to demographic trends (a fall in fertility and enhanced life-expectancy) but also a widening of pension coverage (extension of pension schemes and a lowering of the legal entitlement age in certain countries) and to an improvement in the levels of the pensions themselves.

Even if, particularly in some countries, public expenditure continues to rise, there is no question of it following the predictable curves of demographic trends. OECD calculations have predicted the implications of population aging for public retirement expenditure between 2000 and 2030 : 
TABLE 2

Share of Pensions in national income: Impact of demographic factors

$\begin{array}{lrrrrr} & 1983 & 2000 & 2010 & 2020 & 2030 \\ \text { Germany } & 14.0 & 16.4 & 19.8 & 21.7 & 28.2 \\ \text { Belgium } & 14.1 & 13.9 & 14.9 & 17.0 & 21.1 \\ \text { Denmark } & 9.1 & 10.1 & 11.4 & 14.4 & 17.2 \\ \text { Spain } & 9.6 & 11.1 & 11.7 & 12.9 & 15.8 \\ \text { France } & 14.2 & 16.5 & 17.4 & 21.7 & 25.4 \\ \text { Greece } & 10.2 & 12.3 & 13.9 & 14.9 & 16.7 \\ \text { Ireland } & 6.6 & 6.1 & 5.8 & 6.7 & 8.1 \\ \text { Italy } & 16.6 & 19.4 & 22.0 & 25.1 & 30.2 \\ \text { Holland } & 12.6 & 13.5 & 15.2 & 19.8 & 26.0 \\ \text { Portugal } & 8.2 & 10.9 & 11.2 & 12.4 & 15.0 \\ \text { Great-Britain } & 8.3 & 7.6 & 7.7 & 8.8 & 10.7\end{array}$

Source: R. Holzmann and M. Maguire: "Les régimes publics de pensions et le vieillissement de la population: conséquences pour les pays de l'OCDE', a paper prepared in 1987. These projections are based on an assumption of stability in the level of contributions per beneficiary as against national income per capita, in the degree of activity of the elderly and in the proportion of the latter benefitting from contributions.

Indeed, population ageing which in relative terms was already significant between 1970 and 1985 will continue in all western countries and between 2005 and 2010 , for social security expenditure, will achieve alarming proportions. The predictable trend for the proportion of persons over 60 years or more as a percentage of the total population is as follows:

$T A B L E 3$

Persons over 60 years or more as a percentage of total population

$\begin{array}{lrrrrr} & 1950 & 1980 & 1990 & 2000 & 2025 \\ \text { Germany } & 14.0 & 19.3 & 20.7 & 23.9 & 31.1 \\ \text { Belgium } & 16.0 & 18.3 & 19.9 & 20.9 & 26.9 \\ \text { Denmark } & 13.4 & 19.4 & 20.2 & 20.5 & 29.7 \\ \text { Spain } & 10.9 & 14.9 & 16.8 & 18.5 & 21.9 \\ \text { France } & 16.2 & 17.2 & 18.3 & 19.4 & 25.9 \\ \text { Greece } & 10.0 & 17.4 & 19.3 & 21.7 & 23.8 \\ \text { Ireland } & 14.8 & 14.8 & 13.6 & 12.3 & 17.0 \\ \text { Luxemburg } & 14.5 & 17.6 & 18.8 & 20.9 & 28.6 \\ \text { Italy } & 12.2 & 17.2 & 19.8 & 21.9 & 26.8 \\ \text { Holland } & 11.5 & 15.7 & 17.2 & 18.6 & 30.1 \\ \text { Portugal } & 10.5 & 14.6 & 15.9 & 16.6 & 22.1 \\ \text { Great-Britain } & 15.5 & 20.1 & 20.7 & 20.3 & 25.7\end{array}$

Source: Calculations based on datas and projections in the ILO's "Working Population 1950-2025", Geneva 1988.

This trend will lead to a very sharp rise in the dependancy ratio of non-workers to workers which by the year 2000 will have exceeded $15 \%$ in several countries. Let us now look at predictions calculated by the IMF (International Monetary Fund) for several large countries under two scenarios: 
TABLE 4

Dependency of non-workers to workers

\begin{tabular}{|c|c|c|c|c|c|c|c|}
\hline & \multirow[b]{2}{*}{1980} & \multicolumn{3}{|c|}{ Baseline Scenario } & \multicolumn{3}{|c|}{ "Greater Aging" Scenario } \\
\hline & & 2000 & 2010 & 2025 & 2000 & 2010 & 2025 \\
\hline \multicolumn{8}{|l|}{ Overall dependency rate 1} \\
\hline Canada & 48.1 & 47.0 & 46.8 & 61.3 & 46.4 & 44.9 & 59.2 \\
\hline France & 57.5 & 55.3 & 51.5 & 57.2 & 51.0 & 50.2 & 59.5 \\
\hline Germany, Fed. Rep. of & 47.9 & 50.4 & 54.1 & 60.8 & 47.7 & 51.5 & 59.2 \\
\hline Italy & 55.0 & 52.8 & 53.1 & 56.7 & 50.8 & 51.1 & 56.4 \\
\hline Japan & 48.4 & 48.4 & 58.1 & 63.2 & 51.5 & 60.0 & 65.0 \\
\hline United Kingdom & 56.3 & 53.4 & 52.2 & 59.0 & 53.1 & 50.6 & 59.0 \\
\hline United States & 51.3 & 50.6 & 49.5 & 61.8 & 48.6 & 46.6 & 61.0 \\
\hline Average & 52.1 & 50.9 & 52.2 & 59.8 & 49.9 & 50.7 & 59.9 \\
\hline \multicolumn{8}{|l|}{ Elderly dependency rate ${ }^{2}$} \\
\hline Canada & 14.1 & 16.7 & 18.6 & 31.1 & 17.3 & 19.4 & 33.1 \\
\hline France & 22.0 & 21.7 & 20.6 & 24.8 & 20.5 & 21.9 & 30.8 \\
\hline Germany, Fed. Rep. of & 22.9 & 25.6 & 31.9 & 37.9 & 25.6 & 32.4 & 40.4 \\
\hline Italy & 20.9 & 24.0 & 25.4 & 29.8 & 24.4 & 26.9 & 33.6 \\
\hline Japan & 13.4 & 22.1 & 28.8 & 34.6 & 26.4 & 34.2 & 41.6 \\
\hline United Kingdom & 23.1 & 23.2 & 24.0 & 29.4 & 23.7 & 25.3 & 33.1 \\
\hline United States & 16.9 & 19.6 & 20.6 & 31.4 & 20.5 & 22.6 & 37.2 \\
\hline Average & 19.1 & 21.7 & 24.3 & 31.2 & 22.6 & 26.1 & 35.7 \\
\hline
\end{tabular}

Source: Aging and Social expenditure in the major industrial countries 1980-2025, Paper no 47, IMF, Washington DC, Sept. 1986.

${ }^{1}$ The population of the under fifteens and over sixty-fours as percentage of the population between 15 and 64 years.

${ }^{2}$ The population of the over sixty-fours as a percentage of the population between 15 and 64 years.

It would seem therefore that the enhancement of life expectancy and the improvement in retirement pensions, both in themselves positive trends, are going to make necessary radical changes in our social, employment and continuous training polices.

\section{Psycho-social benefits of the 4th pillar}

We shall deal with these briefly since to most of us they are evident. The main consideration is that people, when they reach 60 , frequently want to keep in some sort of touch with their profession or with the working world in general - especially if they are qualified and feel they still have something valuable to contribute. But at the same time - and this sometimes occurs before they are 60 - most feel the need for a change in the pace of their professional lives and would be content to work part-time on a more flexible basis. Indeed several recent studies have shown the following two phenomena:

a) A growing number of workers, especially the skilled ones, would wish to avoid a sudden change-over to full retirement. A single example will suffice: In November 1985, the National Productivity Institute of Quebec conducted an in-depth survey into the attitudes of 2000 
workers representative of Canada's working population. The survey found that $52.5 \%$ wanted to remain professionally active on reaching retirement age: $46 \%$ on a part-time basis and $6.5 \%$ full-time. But most interesting of all was the fact that the higher the professional echelon the more positive the response. In upper management more than $80 \%$ wanted to remain professionally active after retirement age, three fourths of them on a parttime basis.

b) A sizeable proportion of those currently in retirement would, if the opportunity arose, be happy to exercise some sort of professional activity. Again, a single example will suffice : Out of 5000 American retirees of 65 years or more, more than a third would be happy to be working part-time. If offered the opportunity of working not only part-time but also on a flexible basis, more than one half said they would be glad to return to work. Moreover a majority felt themselves to be less choosy about conditions of employment than younger workers.

Finally, most of those who have continued to work after retirement, especially on a part-time basis, declared themselves highly satisfied.

\section{Economic aspect of the 4th pillar}

\subsection{Development of part-time employment (PTE)}

Stated briefly, between 1973 and 1985, our economies saw a doubling of part-time employment. The following figures for just a few countries demonstrate the current state of growth in part-time work:

\section{$T A B L E 5$}

Part-time employment as a \% of all employment in 1987

$\begin{array}{ll}\text { Denmark } & 24 \\ \text { Holland } & 29 \\ \text { Great-Britain } & 22 \\ \text { Germany } & 13 \\ \text { France } & 12 \\ \text { EEC (average EUR 10) } & 14 \\ \text { USA } & 20 \\ \text { Sweden } & 25\end{array}$

Source: Eurostat, Labour Force Survey Results 1987, Luxemburg 1989.

Indeed the notion of PTE has increasingly broadened to include flexible work and thus to embrace temporary and self-employment.

According to a very recent survey, "The Contingent Economy" (1989) by R. S. Belous, an economist with the National Planning Association, contingent employment (that is parttime and temporary work and self-employment) increased by $28 \%$ in the United States between 1980 and 1988 (accounting for 8.1 million additional jobs) while global employment grew by only $14 \%$. Flexible work now accounts for more than a quarter of all employment. 
These figures become all the more significant when one adds those who work on the "black" market which is mostly part-time and which also involves, contrary to common belief, skilled personnel both before and after retirement age. "Black" labour is now estimated to account for about $15 \%$ of all employment.

Will the growth in PTE continue?

The majority of experts believe it will. According to a study carried out in Great Britain by the Institute for Manpower Studies, part-time work in this country will continue to grow and substantially: from $22 \%$ of all employment in 1985 it will rise to $25 \%$ in 1990 and $30 \%$ in 1995 . By 2000 , more than one third of all workers will have part-time jobs.

What is more, 3/4 of all part-time jobs in the European Community are in the services sector. And it is precisely in this sector that, over the next two decades, $90 \%$ of all new jobs created in our countries will be found.

\subsection{Employment of the over-sixties}

\subsubsection{Part-time employment}

For the time being, it is true that in most countries the number of workers aged sixty years or more has been on the decrease. And yet those who remain active are increasingly working part-time, especially after the age of 65 , as shown in the following table.

TABLE 6

Part-time employment of workers aged 65 or more in 1986

$\begin{array}{lll}\text { Great-Britain } & 66 & 80 \\ \text { Holland } & 52 & 64 \\ \text { Germany } & 40 & 58 \\ \text { France } & 36 & 43 \\ \text { Denmark } & 30 & 66 \\ \text { Belgium } & 21 & 34 \\ \text { USA - } 1984 & 46 & 60\end{array}$

Source: OECD, Employment Outlook, Paris, 1988.

In the USA a vast survey undertaken in 1986 by the Department of Social Security examined the retirement situation of $673^{\prime} 000$ men and 520'000 women. Some of the main findings were :

- more than one retiree in 5 ( $24 \%$ of men and $22 \%$ of women) was found to be working from 18 to 30 months after the legal retirement age; 
- most of those working are not employed full-time : $83 \%$ of men and $73 \%$ of women work shorter hours; the mean number of hours worked per year is : 1'040 for salaried workers (approximately half-time), 931 for self-employed men, 800 for self-employed women;

- more than $80 \%$ of these working retirees wish to continue working part-time "as long as they are able to";

- $36.6 \%$ of men and $12.8 \%$ of women are self-employed, a proportion higher than national average for all workers;

- the self-employed continue to work after retirement age in greater proportion than salaried workers.

\subsubsection{The quality of the work of the over sixties: a challenge for the Service Economy}

Increasingly our economies are becoming structured around service functions as the new technologies gradually replace traditional labour in industrial production. The service professions are physically less demanding and open up more opportunities for flexible work patterns, such as part-time and temporary work. Broadly speaking the jobs they involve can quite easily be handled by persons over the age of sixty, especially on a flexible basis and without there being any need to set overall age limit. Indeed the "4 Pillars" might well become the social policy of the Service Economy.

According to a survey made in 1985 by the American Retirees Association on a sample group of 400 firms representative of enterprises with more than 50 employees, $72 \%$ of heads of personnel felt the main assets of the "elderly" worker to be not only his professional experience, competence and sense of responsibility but also emotional stability and the capacity to respond positively to a situation of crisis. As far as productivity was concerned, where both quality and speed were taken into account, it was felt that the "elderly" worker came out rather well, in any case a good deal better than the prevailing prejudice would have us believe. The firms questioned were of the opinion that the main shortcomings of the worker over sixty were his diminished physical strength and limited ability to adapt to new technologies. Most people, however, agreed that better management of human resources continuous training, job-switching and more flexible hours, etc. - are likely to improve the performance of elderly workers well beyond present levels.

In another American study, this time a "scientific one" (and not an opinion survey) entitled "Aging and Human Performance" and edited by Neil Charness, ${ }^{1}$ it was found that the relationship between age and productivity at work depended above all on the type of task undertaken. There follow some examples of the findings in this study as summarised by Dr Paul R. Sparrow:

- Administrative and Sales work: most of the case-histories in this study show that age has no effects on productivity;

- Semi-skilled and skilled manual work: it was found that here the relationship could be expressed in a shaped curve, that is, the productivity of young workers is low to begin with, rises to a peak between 30 and 40 years and thereafter gradually redescends. Nevertheless, the productivity of older workers was substantially higher than that of the younger ones;

\footnotetext{
${ }^{1}$ Studies in Human Performance, John Wiley and Sons, 1985.
} 
- Management and Direction: here productivity is extremely difficult to measure: however the few studies that do exist show that age does not affect productivity in decisionmaking. "Elderly" and "young" managers tend to work differently rather than better or worse than each other;

- Technical and professional (lawyers, economists, doctors, etc.) work : it appears that professionals who prove to be highly competent at the outset of their career remain so throughout their professional life; only the performance of the less ables seems to be adversely affected by aging: in certain highly specialised jobs, stress increases with age (e.g. air-traffic controllers).

In its conclusions, the study states inter alia that some of the adverse effects of aging can be obviated with continuous training, especially in job involving complex operations. Where such training is provided, the stability, loyalty, experience and job satisfaction of the "elderly worker" will be found to more than offset any lead in productivity the young worker may have over him.

\subsection{The future of the employment market}

We have already, albeit briefly, examined the probable growth of PTE. One crucial factor, however, which will increase job opportunities for the over sixties is revealed in the predicted pattern of development for the working population as a whole. The International Labour Office has estimated that, between 1980 and the year 2000, the population of 15 to 19 year olds will have diminished by:

$\begin{array}{ll}\text { Great Britain } & 19 \% \\ \text { France } & 10 \% \\ \text { Italy } & 32 \% \\ \text { Germany } & 42 \%\end{array}$

Source: ILO, 1985, Geneva, in "Young people and the Labour Market, A challenge for the 1990s", National Economic Development Office, London, 1988.

\section{International comparisons of population aged 15-19 years}

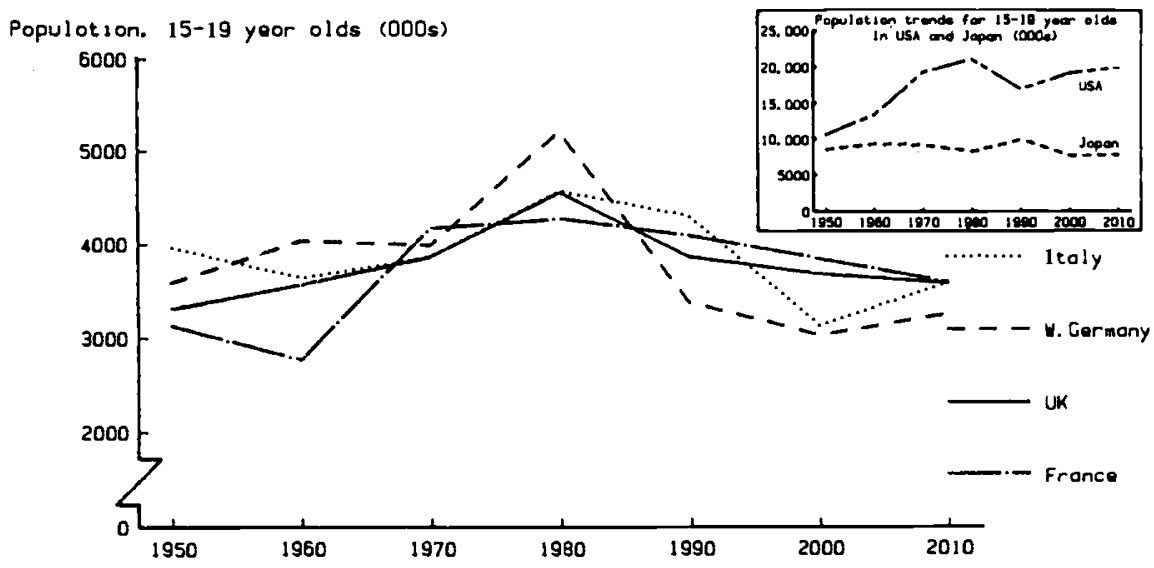

Source: ILO, 1985 
Although a large number of economic variables are involved, with frequently complex relationships, as of the mid 1990's at any rate a shortage of young workers is foreseen for a number of countries. This shortage of young workers will not necessarily be offset by an increase in job-offers for the over sixties. But if young, especially skilled, workers cannot be found to fill professional vacancies, older ones will increasingly be asked to stay on longer. This new employment practice will doubtless need the same type of social and political support as that enjoyed by the early-retirement schemes of the seventies and the eighties.

Several surveys and various indicators point to both private and public firms being only too ready to continue to benefit from the professional experience and high motivation of skilled workers reaching the end of their careers. American firms, in particular, have already adopted new employment policies for their management staff over sixty years so as to retain the latter for as long as possible.

Indeed, this shortage of skilled workers together with the improved state of health of workers over sixty has led in the Soviet Union to changes in patterns of employment for retirees. In Georgia, for example, the employment of retirees increased from 16 to $26 \%$ between 1970 and 1985 . This proportion is broadly comparable to the national average of $25 \%$ for working retirees. Most work part-time ( 4 hours per day) and continue to receive a fullpension.

\section{The prolonging working life - European and American experiences}

Throughout the seventies, many European countries enacted measures to promote early retirement primarily in an attempt to relieve the pressure of unemployment but also as a means of improving productivity. Currently, however, the demographic and financial prospects for pension schemes, the net improvement in the unemployment situation and predicted trends on the labour market are beginning to alter peoples' attitude to workers over 55 or 60 . Even prior to 1980 Sweden had introduced an attractive partial retirement scheme. Recently several countries have adopted or are about to adopt measures designed to ease the transition from working life to retirement and ipso facto bring about a lenghthening of the former.

There follows, for a selection of countries, some account of the prevailing situation and of legislations.

\subsection{Sweden and the Nordic countries}

\section{Sweden}

In 1976, the Partial Retirement Bill lowered the legal age for retirement from 67 to 65 years and introduced a scheme of partial retirement combined with part-time employment. The main features of this scheme are as follows:

- designed for workers between 60 and 70 years of age;

- part-time employment must remain within a minimum of 17 hours and a maximum of 35 hours per week; the self-employed must cut their work-hours by one half;

- no reduction in the full pension of workers of 65 years or more;

- up to the age of 65 income is supplemented by a "partial pension", the latter amounting in all from 85 to $90 \%$ of the earlier salary. 
The scheme has been warmly welcomed by employees and employers alike. Employers saw this as an opportunity to increase productivity and to reduce absenteeism which tends to be relatively high after 60 years. At the beginning of the 80 's the scheme proved to be so popular with employees that by $198240 \%$ of those concerned had opted for it. Having initially caught on with workers in the secondary sector, partial retirement has now become particularly popular with employees in services. Subsequent to 1982 , following the financial difficulties which beset social security and the consequent fall in the level of partial pensions, the scheme began to prove less popular and at one point was opted for by hardly $25 \%$ of the workers concerned. Today, however, with the restoration of partial pensions to earlier levels and improvements on the labour market, the scheme has recovered its former popularity.

\section{Denmark and Finland}

They have both adopted partial pension schemes which came into force at the beginning of 1987. In Denmark, the new "Law on Partial Retirement" allows employees and the self-employed from 60 to 67 years to reduce their working hours and to receive a partial pension. The conditions have been kept to a minimum. Those concerned:

- must have worked at least 10 years in Denmark and contributed full-time to the pension fund for 10 years;

- must be prepared to reduce their working hours by at least one fourth. They consequently expect to work between 15 and 30 hours per week.

Changes in the combination opted for may occur at $621 / 2$ or at 65 years. In Finland, the system is very similar, except that there is no agelimit to the 4 th pillar.

\subsection{Great-Britain}

At present, only a minority of retirees continue in officially remunerated employment. But, as elsewhere, the financial prospects for pension schemes as well as predicted trends for the labour market are causing people to turn to the 4th pillar as a possible solution for the future. Indeed, following the fall in the birth-rate during the 70's, the number of youngsters reaching the labour market will decline by $25 \%$ between 1986 and 1995 . Moreover, the already substantial presence of women on the labour market (almost $60 \%$ ) leaves little room for any sizeable growth.

It is predicted that over the next six years, between, that is, 1989 and 1995, the British economy will require a fresh intake of one and half million workers. In June 1989, the Prime Minister launched a debate designed to focus attention on ways of encouraging parttime employment for persons who have already reached the legal age for retirement. And in the spring of the same year the Government had already granted persons of legal retirement age the right to continue working without retaining their full pension. The growth trend for the number of the self-employed among men of over 55 is also revealing:

$\begin{array}{lll} & 1979 & 1986 \\ 55-59 \text { years of age } & 8.6 \% & 17.1 \% \\ & \left(124^{\prime} 000\right) & \left(182^{\prime} 000\right) \\ 60-64 \text { years of age } & 9.6 \% & 16.2 \% \\ & \left(85^{\prime} 000\right) & \left(111^{\prime} 000\right)\end{array}$




\subsection{Germany}

The market aging of this country's population, primarily the outcome of a fall in the birth rate between 1965 and 1975, has, as elsewhere, made necessary a review of its pensions system and of socio-economic policy. The following two tables clearly illustrate this demographic trend, as also the predictable increase in retirement pensions if drastic measures are not taken.

\section{$T A B L E 7$}

Population Development in the FRG (Model IC - 1966)

\begin{tabular}{lrrrr} 
Age categories & 1985 & 2000 & 2015 & 2030 \\
$0-5$ & 3,0 & 2,6 & 2,0 & 1,5 \\
$0-15$ & 9,1 & 8,8 & 6,2 & 5,2 \\
$20-60$ & 34,6 & 33,4 & 30,5 & 22,3 \\
60 and more & 12,5 & 15,1 & 16,0 & 18,3 \\
\hline Total population & 61,0 & 60,3 & 55,4 & 47,8 \\
& & 1985 & 100 & \\
$0-5$ & 100 & 86 & 66 & 52 \\
$0-15$ & 100 & 96 & 68 & 57 \\
$20-60$ & 100 & 96 & 88 & 65 \\
60 and more & 100 & 121 & 128 & 147 \\
$0-20 / 60$ and more & 100 & 102 & 94 & 97 \\
\hline Total population & 100 & 99 & 91 & 78
\end{tabular}

Source: Social expenditure and population development : Fears, hopes and facts, P. Rosenberg, International Social Security Review, 2, 1988, Geneva.

\section{TABLE 8}

Social Expenditure by function $1985-2030^{*}$ in constant** 1985 prices

\begin{tabular}{lrrrr} 
Functions (\% of GDP) & 1985 & 2000 & 2015 & 2030 \\
Households and families & 3.7 & 3.3 & 2.8 & 2.8 \\
Health & 10.3 & 9.7 & 9.3 & 9.9 \\
Employment & 2.0 & 0.8 & 0.4 & 0.5 \\
Old-age and Survivors & 11.1 & 12.5 & 13.6 & 19.7 \\
Compensation & 1.0 & 0.4 & 0.0 & 0.1 \\
Housing and Savings & 1.6 & 1.1 & 0.9 & 0.1 \\
General Emergency aid & 0.2 & 0.2 & 0.2 & 0.2 \\
\hline Total Social Expenditure & 29.9 & 28.1 & 27.3 & 33.8
\end{tabular}

* Totals do not add up to due to rounding-off of percentages

** In macro economic terms, subject to relative variations in price. 
A new law enacted during the first half of 1989 makes immediate provision for several changes in the occupational pension ( $2 \mathrm{~d}$ pillar) system some of which will help to promote the 4th pillar:

- from 2001 to 2012 the legal retirement age will increase from 60 years (women) and 63 years (men) to 65 years for all;

- the retirement age is now flexible: one can benefit from a pension earlier or can go on working as long as possible; there is no longer any age limit;

- one can continue to draw a partial pension $(1 / 3 ; 1 / 2 ; 2 / 3)$ while working part-time $(2 / 3$; $1 / 2 ; 1 / 3$ ) without any age limit.2

\subsection{Italy}

For several years now the Italian Parliament has been studying a revision of retirement legislation. If the current Bill were to be adopted, the legal retirement age would gradually (over 10 years) be pushed back from 55 to 60 years and might subsequently be raised even further. A second pillar, based on a capitalisation scheme, would be made compulsory. It is also envisaged that employment for persons of sixty and over would become possible in public services (schools, museums, parks, libraries, etc.) as a way of achieving the social integration of the elderly and reducing "black" labour.

Recent interviews with two of the country's largest unions (CGIL and CISL) show clearly that their attitude on all these issues is beginning to change. They hold the view that the current system of very early retirement for Italian workers is nothing short of disastrous for social security financing. They believe, further, that flexible and gradual retirement should become the norm, and are proposing that new work patterns (part-time and temporary employment) be developed - especially for persons over 55 and 60 years - and combined with partial retirement.

According to a survey made in 1987 by DOXA (Foundation for Statistical Research and Public Opinion Analysis), currently only $9 \%$ of sixty years olds and over have paid jobs, although $38 \%$ of this age would like to be employed especially on a flexible basis. Generally speaking, the pattern whereby "the new generation replaces the old", it is thought, should disappear and Italians are increasingly becoming aware of the dynamism of a population group previously thought as being somewhat "past it", and of the need to keep them integrated professionally for sound social and financial reasons.

This and other data are to be found in a preliminary study by the Geneva Association entitled "The 4 pillars in Italy", March 1989.

\subsection{Switzerland}

As in Germany and Italy, population aging is a major issue. The current legal age for retirement is 62 years for women and 65 years for men. A closing of this age-gap between the sexes is foreseen.

An ordonnance of September 1987 provides for "à la carte" flexible retirement for Federal civil servants and railway employees between 60 and 65 years. At 60 , a Federal employee may opt for retirement with a slight reduction in the pension or for partial

\footnotetext{
${ }^{2}$ See for more details the articles in this issue by W. Steinjan, J. Kruse and by G. Laskonski.
} 
retirement until 65 should he remain active part-time. Those in socio-professional circles want this law to snow-ball into other sectors and be reflected in the collective agreements which govern the social and financial organisation of the majority of the country's workers.

\subsection{United States of America}

As early as 1983 the USA decided to rise the already relatively high (65 years) legal retirement age. Between 2000 and 2027, this age will gradually move from 65 to 67 years.

The progressive aging of the American population, as shown in the following tables, and the imminent shortage of young skilled workers has already forced some firms to delay the retirement of upper and middle management staff or to keep them on part-time.

\section{TABLE 9}

Older Americans in total population, selected years, 1900-2050, actual and projected

\begin{tabular}{lccccr} 
& \multicolumn{2}{c}{ Aged 65 and over } & \multicolumn{2}{c}{ Aged 85 and over } & Total \\
Year & $\begin{array}{c}\text { Number } \\
\text { (in thousands) }\end{array}$ & $\begin{array}{c}\text { Percentage of } \\
\text { total population }\end{array}$ & $\begin{array}{c}\text { Number } \\
\text { (in thousands) }\end{array}$ & $\begin{array}{c}\text { Percentage of } \\
\text { total population }\end{array}$ & $\begin{array}{c}\text { Population } \\
\text { (in thousands) }\end{array}$ \\
1900 & 3,084 & $4.0 \%$ & 123 & $0.2 \%$ & 76,303 \\
1910 & 3,950 & 4.3 & 167 & 0.2 & 91,972 \\
1920 & 4,933 & 4.7 & 210 & 0.2 & 105,711 \\
1930 & 6,634 & 5.4 & 272 & 0.2 & 122,775 \\
1940 & 9,019 & 6.8 & 365 & 0.3 & 131.669 \\
1950 & 12,270 & 8.1 & 577 & 0.4 & 150,967 \\
1960 & 16,560 & 9.2 & 929 & 0.5 & 179,323 \\
1970 & 19,980 & 9.8 & 1,409 & 0.7 & 203,302 \\
1980 & 25,544 & 11,3 & 2,240 & 1.0 & 226,505 \\
1984 & 27,971 & 11.8 & 2,615 & 1.1 & 236,477 \\
1987 & 29,836 & 12.3 & 2,867 & 1.2 & 243,400 \\
1990 & 31,697 & 12.7 & 3,313 & 1.3 & 249,657 \\
2000 & 34,921 & 13.0 & 4,926 & 1.8 & 267,955 \\
2010 & 39,195 & 13.8 & 6,551 & 2.3 & 283,238 \\
2020 & 51,422 & 17.3 & 7,081 & 2.4 & 296,597 \\
2030 & 64,581 & 21.2 & 8,612 & 2.8 & 304,807 \\
2040 & 66,988 & 21.7 & 12,834 & 4.2 & 308,559 \\
2050 & 67,411 & 21.8 & 16,034 & 5.2 & 309,488
\end{tabular}

Source: U.S. Congress, Senate, Special Committee on Aging, Aging in America: Trends and Projections, 1987-88 ed. (Washington, DC: U.S. Governement Printing Office, 1988), tables 1-2; U.S. Department of Commerce, Bureau of the Census, United States Population Estimate, by Age, Sex, and Race: 1980-87, Current Population Reports, series P-25, no. 1022 (Washington, DC: U.S. Government Printing Office, 1988). 
TABLE 10

The US population is growing older (Median age)

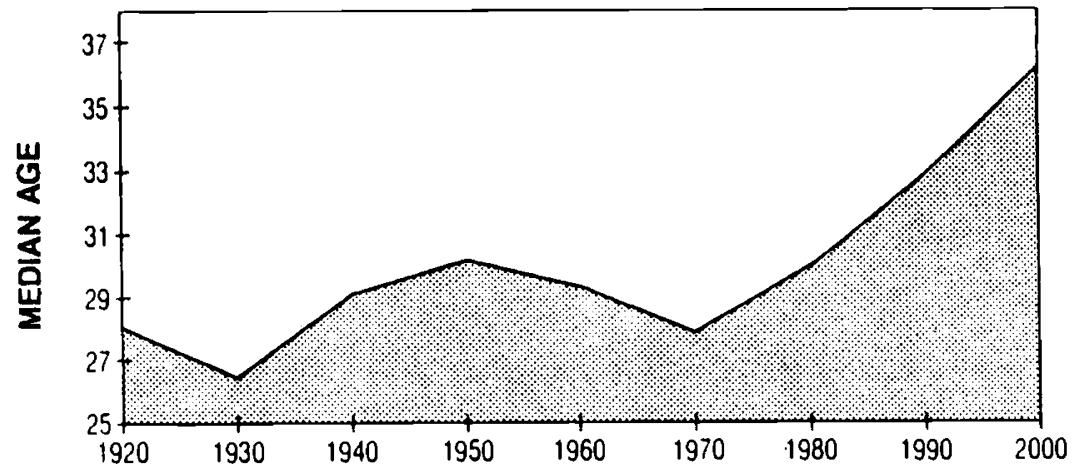

Source : U.S. Bureau of the Census, "Current Population Reports", Series P-23, No. 138, Table 2-9.

Firms which already use the 4th pillar by retaining retirees on a part-time or temporary basis are more than satisfied with the experience. ${ }^{3}$ A survey made as far back as 1984 by Russell Reynolds Associates Inc. of 200 heads of firms who have retired 2 years earlier showed that $61 \%$ of the respondents had resumed some kind of remunerated activity during the 18 months that followed their employment leaving. $55 \%$ of the latter were selfemployed or consultants working on a flexible basis (only 1/3 had returned to full-time employment). $32 \%$ are members of Boards of Governors. The other pursue commercial or philanthropic activities. Interest in their work of the sense of being able to make a contribution to a firm or to the community at large are mainly what motivate those highly professional persons. ${ }^{4}$

Moreover, several programmes have recently been launched by universities (e.g. University of Vermont) or by firms (e.g. Polaroid Corporation, Cambridge, Massachussets) for professionals taking early retirement so as to prepare them for "second careers" as secondary-school teachers. The aim here is twofold: to supply schools with teachers with sound professional and life experience and to enable managers or very skilled people in their fifties to find fresh sources of fulfillment in new fields.

${ }^{3}$ In this connection, see the interesting experience of one insurance company, the Travelers Insurance Companies, as described in "Integrating the Elder into the Labour Force: Consequences and Experience for Insurance", by P. Libassi, The Geneva Papers on Risk and Insurance, no. 49, October 1988, pp. 350-360.

${ }_{4}$ The results of the survey have been published by Russell Reynolds Associates Inc., 245 Park Ave, New-York, NY, USA. 